\title{
Enterobactérias Patogênicas
}

Seu isolamento das águas superficiais por meio de precipitação química.

\author{
S. JOLY e J. C. MARMO
}

Escola Superior de Agricultura "Luiz de Queiroz» 


\section{INTRODUÇÃO}

Nas águas de superfície, como se sabe, encontram-se normalmente vários grupos de bactérias que, em conjunto, formam a cliamada flora-natural bacteriana.

HENRY (1929), assim os enumerou:

a) bactérias fluorescentes (e. g. Pseudomonas fluorescens);

b) bactérias cromógenas (e. g. Serratia marcescens);

c) Proteus, que ocorrem na matéria orgânica em putrefação;

d) bactérias esporuladas (e. g. Bacillus subtilis);

e) Coccus não cromógenos (e. g. M. aquatilis).

Nessas águas, entretanto, especialmente quando próximas ans centros urbanos, outras bactérias são achadas, bactérias estas que constituem a flora invasora. Estas viltimas podem ser reunidas em dois grupos: as patogênicas e as banais.

Escherichia, Aerobacter, Streptococcus faecalis etc. pertencem a êste último grupo, e embora não façanı nenhum mal ao homem, não convém sejam encontradas nas ácuas de consumo.

Com maior razăo ainda as patogênicas (Shigello, Salmonella, Vibriâo cholerico etc.) não devem alí estar presentes para que epidemias, chamadas de origem hidrica, sejam evitadas.

Há, por isso, grande interêsse para a saide publica en se conhecer a flora das águlas antes que as mesmas sejam entrerrues ao consumo.

Para se evidenciar êsse elemento, há necessidade de exames de lahoratório, que naturalmente informarão do estado sanitário ressas águas.

Os exames norma!mente. não feitos no sentido do se detectar as bactórias banais de tino coliforme que, nor so anresentarem moralmente em rrande número. são muito mais fàcilmente surresendidas na massa d'ácula do atue as natogênicas que, ror terem uma distribuicão muito heterogênia e nor serem geralmente potico numerosas, apresentam orandes dificuldades para serem ali reveladas.

Teòricamente, êsses exames deveriam se dirigir esnecialmente para se descobrir diretamente na água a presença destas últimas bactérias, as patogênicas.

Entretanto, denois de muitas tentativas. os interessatos nesse setnr da saúde nública, devido aos óbices encontrados pela própria natureza de trabalho, acharam muito mais razoável usarem técnicas que, por exames bacteriológicos indiretos, pudessem avaliar o estado sanitário das águas. 
As bactérias do tipo coliforme, consideradas como indicadoras da contaminação, são por êstes exames, as procuradas nas águas, e não os agentes patogênicos, sempre de difícil comprovação e isolamento.

Isto veio facilitar sobremaneira os estudos acêrca da bacteriologia da água, em virtude de ser muito mais fácil descobrir-se, em determinado manancial, a contaminação das águas destinadas ao consumo por meio de bactérias banais oriundas da matéria fecal, do que localizar a presença dos agentes etiológicos das doenças hidricas.

É que, sendo a água, de modo geral, um mau meio-de-cultura, que por isso não permite a fácil multiplicação dêstes germes em sua massa, e sendo usada, além disso, em grandes volumes, que diminuem consideràvelmente 0 teor das bactérias patogênicas que porventura possam ali ter acesso, ficaria êste problema de difícil resolução para um bacteriologista, máxime porque em determinado suprimento.d'água, podem aparecer uns poucos e muito espalhados focos de contaminação, de problemática ou impossivel localização direta.

Por técnica especial, aconselhada pela American Public Health Association, como é sabido, chega-se com relativa facilidade à determinaçäo da presença ou não de coliformes fecais em determinada água, antes de ser a mesma entregue ao consumo.

Realizado o ensaio de presunção, faz-se, em determinados casos, ensaios de confirmação e, se necessário, pratica-se o ensaio completo.

Geralmente só se faz o teste presuntivo na rotina dos trabạthos, deduzindo-se dai o indice-coli; os dois outros por serem mais complexos, implicam em melhor aparelhagem e em técnica mais aprimorada, pelo que só em casos menos comuns é que são executados; além disso, diversas vêzes não são mesmo necessários.

A pesquisa dos patogênicos poucas vêzes se realiza por êsse método; quando praticada, é por via indireta e não faz parte pròpriamente dessa técnica.

Como que para complementar êsse delicado trabalho, tornando o exame muito mais seguro, muitos pesquisadores não se contentam em saber, apenas, se determinada amostra d'água apresenta coliformes, uma vez que em virtude disso se presume ter recebido efluentes de esgotos, carregados de microrganismos patogênicos.

Usando outros métodos, vários hídrobiologistas, querendo dar um passo mais firme e saber com certeza se as águas destinadas ao consumo apresentam ou não germes patogênicos, procuram ali, para isso, diretamente, a presença especialmente, de Salmonellas 
e Shigellas, ou sejam os agentes das doenças hídricas mais difundidas.

Isto, entretanto, que foi durante algum tempo considerado um mito (BUTTIAUX, 1951) continua sendo um problema quase insolúvel, dadas as dificuldades de se estar sempre em presença de grandes massas de água e de uns poucos germes ali mal distribuidos, que vão perecendo à medida que o tempo passa. É, como os iniciados do assunto sabem, o mesmo problema de se encontrar uma agulha num palheiro; ela está ali, mas seu encontro é problemático e bastante dificultoso, quase impossível mesmo.

Como, entretanto, segundo alguns teóricos, as dificuldades foram postas para serem vencidas, o número de bacteriologistas que se dedicam a êsses estudos, vem ùltimamente aumentando.

DIÉRNET, RUSSEL, KRUMWIEDE, KLIEGER, HAJNA, BAILEY, SURRACO \& PEREYRA, MONTEVERDE, SINGER, BUTTIAUX, COSTA \& VERNIN, BARACCHINI, PUPO etc. apresentaram técnicas que, usadas para isso, têm proporcionado alguns resultados favoráveis.

Os métodos que maiores contribuições trouxeram para o problema em foco foram os de se concentrar a flora bacteriana encontrada na água, seja por meio de precipitantes ou por intermédio de membranas filtrantes ou ainda por aglutinantes.

Para isso, em lugar de se lançar mão de amostras relativamente pequenas, êsses novos métodos prevêem volumes bem maiores dos usados pelo método "standard".

Além disso, em vez de se usar para a semeadura pequenos volumes d'água da amostra, como foi colhida, o que se faz nos métodos padrões, toma-se de um volume maior d'água que possibilitará talvez o encontro mais fácil das bactérias contaminantes.

A água, por êstes últimos métodos, antes de ser semeada, é ainda submetida à concentração bacteriana e às vêzes à centrifugação.

Reunidas as bactérias em um pequeno volume d'ăgua, são elas depois semeadas em meios de enriquecimento ou diretamente em seletivos e depois cultivadas com a finalidade de se conhecer seu comportamento cultural, bioquimico e sorológico.

Além disso, exames microscópicos minuciosos, com. ou sem coloração, são realizados para se determinar a motilidade, a esporulação, a presença de cápsula, o Gram etc., para assim se determinar o gênero e a espécie a que pertençam.

A pesquisa da produção ou não de prodigiosina ou de outros pigmentos também é necessária para se fazer o estudo taxonômico. 
Depois de realizadas tôdas estas operações, as culturas, após a purificação, são por fim enviadas a laboratórios especializados para ali ser feita a confirmação do trabalho de determinação bacteriológica ou se faz a confirmação no próprio laboratório onde os trabalhos foram executados.

\section{MATERIAL E METODOS}

As amostras d'água para os presentes ensaios foram colhidas em diversos córregos e rios dos municípios de Piracicaba, Rio Claro, Itu, Sorocaba, Guarulhos e São Paulo, (Alto da Lapa), como se pode observar no Quadro XIX, usando-se da assepsia recomendada para êsses ensaios e conservando a água das amostras em temperatura baixa, não mais de 24 horas; a grande maioria foi, entretanto, manipulada logo depois de colhida.

O método usado no presente trabalho, foi apresentado por PUPO (1959), sob a forma de um esquema que consiste no seguinte:

a) coleta das amostras d'água com a técnica usual, mas em volume de $500 \mathrm{ml}$, aproximadamente;

b) mistura de $100 \mathrm{ml}$ da águả das amostras colhidas com $1 \mathrm{ml}$ de leite de alumina, que funciona como substância precipitante, de natureza química;

c) depois da mistura água-precipitante ter permanecido no refrigerador durante 2 a 4 horas, despreza-se o líquido sobrenadante, obtendo-se assim um resíduo que é chamado coágulo; a separação será muito mais perfeita se a mistura fôr centrifugada, por exemplo, durante 5 minutos a $2.000 \mathrm{rpm}$;

d) o coágulo depois é semeado com pipetas estéreis nos meios-de-cultura que se seguem - Selenito, Tetrationato, Shigella-Salmonella, Wilson \& Blair e Kristensen; nos dois primeiros, semeia-se cêrca de $1 \mathrm{ml}$ de coágulo e nos três últimos, apenas III gotas; usam-se frascos de Erlenmeyer e placas para os últimos; as gotas são espalhadas logo a seguir com pequeno bastonete de vidro, no sentido horizontal; feita a semeadura, o material é levado para estufa-incubadora, regulada a $37^{\circ} \mathrm{C}$, onde fica por 24 horas;

e) passado êsse tempo, as culturas de enriquecimento, contidas nos frascos, são semeadas em placas, contendo os mesmos meios seletivos acima enumerados; as das placas, provenientes da semeadura do coágulo, são transferidas para tubos de 
cultura, com meios aconselhados por COSTA \& VERNIN e por BARACCHINI; no primeiro dêstes meios obtém-se de preferência microrganismos patogênicos (Salmonelleae ou Proteae) e no segundo, o de BARACCHINI, quase sempre coliformes, não patogênicos (Escherichieae);

f) após a incubação, as culturas das placas, semeadas com material proveniente dos meios de enriquecimento, são examinadas, para se conhecer e repicar apenas as colônias que diferem das aparecidas nas placas que receberam coágulo como inóculo; êsse repique é feito para tubos que apresentam os meios de Costa \& Vernin e de Baracchini;

g) as culturas mantidas em tubos, originadas das placas, são incubadas por 24 horas a $37^{\circ} \mathrm{C}$ e logo depois examinadas, colhendo-se os informes que auxiliarão a determinação taxonômica das cepas.

\section{RESULTADOS OBTIDOS}

Apresentamos adiante, em ordem cronológica de coleta das amostras, os elementos colhidos em laboratório, resultante dos diversos testes a que foram submetidas as cêpas bacterianas isoladas durante a execução do presente trabalho.

Esses resultados foram catalogados nos diversos quadros, onde as cêpas são designadas por uma sigla constituída de dois números, o primeiro dêles indicando a amostra de origem e outro a denominação da cêpa. Nêles não foram incluídos os resultados dos testes de aglutinação, por falta dos antisoros específicos; tão logo essa complementação do trabalho seja realizada, os resultados serão apresentados em publicação ulterior.

\section{DISCUSSÃO}

Amostra 5 - Quadro I.

Das 9 cêpas obtidas, de acôrdo com os caracteres apresentados, uma foi considerada como patogênica (Salmonella), 7 como coliformes e 1 como de um outro grupo. Dos coliformes, 5 se mostraram típicas (Escherichia e Aerobacter) e 1 atípica (Klebsiella). A do outro grupo, foi assim considerada em virtude da pigmentação que apresentou em caldo. 
Amostra 6 - Quadro II.

Tôdas as 5 cêpas obtidas se mostraram como coliformes, sendo 2 típicas (Escherichia) e 3 atipicas (Klebsiella); das Escherichia nenhuma era coli.

Amostra 10 - Quadro III.

Das 14 cêpas obtidas, 4 se comportaram como patogênicas; 4 como coliformes e 6 de outros grupos. Das patogênicas, 2 foram consideradas Salmonella, 15 Shigella, 1 Proteus. Das coliformes, 2 eram típicas (Aerobacter) e 2 outras atipicas (Klebsiella). Das 6 consideradas como de outros grupos, 4 apresentaram Gram (-) mas não fermentaram a glicose; 2 outras não fermentaram a glicose e não cresceram em N.A., pelo que não foi possivel obter o Gram; das Gram (-), uma apresentou em caldo com proteose, pigmento verde, característico de Pseudomonas, o que permitiu a exclusão dessa cêpa da ordem Eubacteriales.

Amostra 12 - Quadro IV.

Das 10 cêpas obtidas, 4 se comportaram como patogênicas (Salmonella, Shigella e Protetus), 4 coliformes atípicos (Paracolobactrum e Klebsiella) e 2 outras como pertencentes a outros grupos; destas últimas, uma apresentou Gram (- - , mas não fermentou a glicose e outra também com Gram (-), glicose $(+)$ lactose $(+)$, por ter apresentado pigmentação roxa em caldo, não foi incluida na família em ensaio.

Amostra 14 - Quadro V.

Das 21 cêpas obtidas, 5 se mostraram como patogênicas, 11 como coliformes e 5 de outros grupos. Das patogênicas, 4 se comportaram como do gênero Salmonella e 1 Shigella. Dos coliformes, 3 se mostraram típicas, 8 atípicas; das típicas, 1 mostrou-se como Escherichia e 2 como Aerobacter; das atípicas, tôdas se mostraram com os caracteres de Klebsiella. Das 5 cêpas de outros grupos, 2, embora mostrassem Gram (-) não fermentaram a glicose; das 3 últimas, por não terem se desenvolvido em N.A. não foi conseguido o Gram.

\section{Amostra 16.}

Tôdas as 13 cêpas obtidas se comportaram como coliformes, sendo que 8 como tipicas (Escherichia e Aerobacter) e 5 como atípicas (Klebsiella). 
Amostra 17 - Quadro VII.

Das 10 cêpas obtidas, 4 apresentaram caracteres de patogênicas e 6 de coliformes; das patogênicas, 2 se comportaram como Salmonella e 2 conı Proteus. Dos coliformes, 2 se mostraram tipicos (Escherichia) e 4 como atípicos (Klebisiella).

Amostra 18 - Quadro VIII.

Das 18 cêpas obtidas, 4 mostraram os caracteres de patogênicas, 12 de coliformes e 2 de outros grupos. Das patogênicas, 2 se comportaram como Shigella e 2 como Proteus. Dos coliformes, 8 eram tipicos e 4 atipicos; dos tipicos, 7 apresentaram caracteres de Escherichia e apenas 1 de Aerobacter. Dos atipicos todos os caracteres obtidos eram de Klebsiella. Das 2 pertencentes a outros grupos, 1 embora tenha apresentado Gram (-), não fermentou a glicose; a outra por ter exibido Gram $(+)$ foi assim considerada, mesmo tendo fermentado a glicose.

Amostra 21 - Quadro IX.

Das 18 cêpas conseguidas, 5 mostraram os caracteres de patogènicas e 13 de coliformes. Das primeiras, 2 se comportaram como Salmonella, 2 como Shigella e 1 como Proteus. Dos coliformes, 10 se comportaram como típicos e 3 como atípicos; dos típicos, 6 eram Escherichia e 4 Aerobacter. Dos atipicos, tôdas se mostram como Klebsiella.

Amostra 22 -. Quadro X.

Das 11 cêpas conseguidas, 2 apresentaram os caracteres de patogênicas, 4 de coliformes e 5 como pertencentes a grupos diferentes. Das patogênicas, 1 se mostrou como Salmonella e outra. embora pertencente à tribo Salmonellae-Gram $(-)$, glicose $(+)$, lactose (-) e urease (-), o gênero nạo chegou a ser determinado. por falta da observação da motilidade, em virtude de se ter perdido a cêpa em estudo. Das coliformes, 1 era típica (Aerobacter) e 3 atípicas; destas últimas, 2 se mostraran como Klebsiella e a outra. embora como coliforme atípica (glicose e lactose com produção apenas de ácido), não pôde ser incluída em qualquer dos gêtleros, por falta das reações de V.M. e V.P. . Das 5 consideradas como pertencentes a outros grupos, 1 se desenvolveu apenas no meio de Baracchini; 3 outras apresentaram Gram (+) e 1 última, que fermentou só a glicose e assim mesmo com formação apenas de ácido; isto permitiria considerar-se como patogênica, entritanto, não foi possível porque faltou o teste de Gram. 
Amostra 23 - Quadro Xl.

Das 29 cêpas obtidas, 8 podem ser consideradas como patogênicas; 11 coliformes e 10 outras de outros grupos. Das patogênicas, 3 mostraram caracteres de Salmonella, 3 de Shigella e 2 de Proteus. Das coliformes, 7 devem ser consideradas como típicas e 4 como atípicas; das típicas, 4 se mostraram como Escherichia e 3 como Aerobacter; das atípicas, tôdas se mostraram como Klebsiella. Das pertencentes a outros grupos, 4, embora apresentassem Gram (-), não puderam fermentar a glicose; 2 outras mostraram também Gram (-) mas por serem esporuladas não puderam ser incluidas em Enterobacteriaceae; 2 outras, embora tenham fermentado a glicose, por falta da reação de Gram não foram consideradas conıo desta família; 2 últimas, por falta de Gram e de ácido em meio glicosado, também não puderam ser incluídas ali.

Amostra 24 - Quadro XII.

Das 12 cêpas conseguidas, 3 se mostraram como patogênicas e 5 como coliformes; 4 năo puderam ser incluidas num ou noutro grupo.

Das patogênicas, 2 se comportaram como Shigella e 1 como Proteus. Das coliformes, 4 apresentaram caracteres típicos do grupo (Escherichia e Aerobacter) e só 1 com o teste de PARR indicando ser Klebsiella. Quatro cêpas não puderam ser consideradas como Enterobactérias, especialmente por falta do Gram; possivelmente, algumas delas seriam ali incluídas, se todos os testes tivessem sido feitos.

\section{Amostra 25 - Quadro XIII.}

Das 17 cêpas conseguidas, 5 se mostraram como patogênicas, 6 como coliformes e 6 de grupos diferentes. Das patogênicas, 3 se mostraram com os caracteres de Shigella e 2 de Proteus. Das coliformes, 3 se mostraram típicas (Aerobacter) e 3 atípicas (Klebsiella). Das que foram consideradas de outros grupos, 1 se comportou como Pseudomonas, $1 \mathrm{com}$ Gram (-) mas sem fermentação de glicose e lactose; de 2 , apesar de apresentarem glicose (+), não foi possivel obter o Gram; outra apresentou-se com Gram $(+)$ e de 1 última, não foi possivel conseguir nem o Gram nem a fermentação da glicose.

\section{Amostra 26 - Quadro XIV.}

Das 19 cêpas obtidas, 2 foram consideradas como patogênicas, 8 como coliformes e 9 como pertencentes a outro grupo. As pato- 
gênicas mostrarant-se como Salmonella. Das coliformes, 5 se mostraram típicas (Escherichia e Acrobacter) e 3 como atípicas (Klebsiella). Entre as consideradas como sendo de outros grupos, 1 mostrou todos os caracteres de Shigella; por ter apresentado pigmento amarelo em caldo, não pôde ser incluida em tal gênero; das outras 8, 1 apresentou esporos pelo que não pôde ser incluida entre as enterobactérias; de 3 , apesar de serem Gram (-), 2 não fermentaram glicose e outra não se desenvolveu em meio contendo êsse açúcar; outra ainda, apresentou glicose (+); porém, sem a coloração de Gram, 2 sem Gram e sem o teste de glicose, e outra, por fim, com Gram (t).

\section{Amostra 27 - Quadro XV.}

Das 15 cêpas obtidas, 1 se mostrou com os caracteres de de patogênica (Proteus), 9 coliformes e 5 de outros grupos. Das coliformes. 5 se mostraram típicas (Escherichia e Aerobacter), 3 atípicas (Klebsiella) e 1 não pôde ser incluída num grupo nem no outio, por falta dos seguintes testes: V.M. e V.P. e glicerol. Das 5 consideradas como sendo de outros grupos, 2 mostraram Granı (-) sendo que 1 delas não fermentou glicose e outra não se desenvolveu em tal meio; 2 apresentaram Gram (+); por fim, de 1 última não foi possivel conseguir nem o Gram nem o desenvolvimento em glicose.

Amostra 28.

Das 17 cêpas conseguidas, 5 se mostraram patogênicas (2 Sal. monella e 3 Proteus); 4 coliformes tipicas (Aerobacter) e 8 de outros grupos. Destas, 1 apesar de mostrar Gram (-), por faita de crescimento en caldo glicosado, não pôde ser incluida no grupo em estudo; outro também com Gram (-), não apresentou habilidade para fermentar glicose; das outras 6 , não foi possivel obter o Gram, sendo que fermentou glicose e 5 não se desenvolveram em meio contendo êsse açúcar.

\section{Amostra 29 - Quadro XVII.}

Das 18 cêpas consegutidas, 5 se comportaram como patogênicas (4 Salmonella e 1 Shigella), 5 coliformes e 8 como de outros grupos. Das coliformes, 4 se mostraram típicas (Aerobacter) e 1 atípica (Klebsiella). Das cêpas dos outros grupos, 4 se mostraram esporuladas, 1 com Gram e glicose positivos, 2 com glicose $(+)$ porém sem Gram; por fim, 1 última sem Gram e sem desenvolvimento em glicose: 


\section{Amostra 41 - Quadro XVIII.}

Das 15 cêpas que foram conseguidas, 2 se comportaram como patogênicas (Salmonella e Proteus) e 13 como que de outros grupos; destas, 4 apresentaram Gram (-) sendo 3 com glicose com e uma esporulada e sem habilidade para fermentar a glicose; $7 \mathrm{com}$ Gram (+), pelo que foram excluidas de Enterobacteriaceae; por fim, de 2 outras não foi possivel obter Ciram nem fermentação em caldo glicosado.

Adiante encontra-se v quadro XIX com a distribuição dessas cêpas, especialmente em tribos.

Por êsse quadro, nota-se que foi possivel obter 271 cêpas em 18 amostras estudadas, sendo 43 cêpas da tribo Salmonelleae, 18 da Proteae, 126 Escherichieae e 84 de outros grupos; apesar de se teren repicarto as cêpas em vários nneios adequados para a produção de prodigiosina (soja, batata, etc.), nenhuma delas mostrou habilidade para tal, de modo a não poderem ser consideradas como pertencentes a triho Serrdtieae: isto fêz com que grande narte das cepas fôssem consideradas como pertencentes a outras tribos dentro de Enterobarteriacede.

O quadro XX apresenta as enterobactérias ohtiras, dist-ihui. das em gêneros. Por êle, nota-se cule, das patnoêniras foi a Salmonella em maiur número e das coliformes, a Klebsiella è que se apresentou com maior freqüência .

\section{RESUMO E CONCLUSÕES}

Os autores trabalhando com o esquema de PUPO, aconselhado para 0 isolamento de enterobactérias patogênicas diretamente das árulas e com 18 amostras coletadas em vários córregos e rios da bacia hidrográfica do Tietê, conseguiram obter e estudar 271 cêpas bacterianas, sendo 61 patogênicas, 126 coliformes e 84 periencentes a outros grupos. Implicitamente, conseguiram também obter elementos sôbre a natureza da flora bacteriana invasora dessas águas, que, para a maioria dos mananciais estudados, constitui observaçăo inédita.

Diante dêsses resultados as conclusões seouintes se destacam:

a) o esquema ensaiado, presta-se para a sua finalidade, pois que de 271 cêpas obtidas, 61 mostraram caracteres de patogênicas, o que permite uma avaliação de $22,14 \%$ sôbre o total;

b) embora êste número possa aparecer pequeno isto não depōe contra o método usado, uma vez que se considerem as dificuldades inerentes à natureza do trabalho. 


\section{SUMMARY}

Enterobacteria of pathogenic group were isolated directly of superficial waters using Alumina Milk as precipitate, being 23 Salmonella, 19 Shigella and 17 Proteus from 18 samples which were collected in brooks and rivers of São Paulo, Brazil.

\section{LITERATURA CITADA}

BAILEY, S. F., and J. R. LACY - A modification of the Klieger lead acetate medium. J. Bact., 13: $183-189,1927$.

BARACCHINI, O. - Identificaçăo de Enterobactérias. O Hospital, 49 (4): 135-137, 1956.

BUTTIAUX, R. - L'Analyse Bactériologique des eaux de consommation. E. M. Flammarion. Paris, 6:0 - 1951 .

COSTA, G. A., e C. S. VERNIN - Sôbre uma modificaçăo do meio de Monteverde. Memórias do Instittıto Oswaldo Cruz, 53 (1): 105-114. 1955.

HAJNA, A. A. - Triple sugar iron agar medium for the identification of intestinal group of bactéria. J. Bact., 49: 516-517, 1945.

HENRY, H. - A system of Pacteriology in relation to medicine. London III: $1-49,1929$.

KLIEGER, I. J. - Modification of culture medium used in the isolation and differentiation of typhoid, dysentery and allied baccilli. J. Exper. M., 28: 319-322, 1918.

KRIJMWIEDE, C. J., and L. A. KOHN - A triple sugar modification of the Russel double-sugar medium. J. Med. Res., 37: 225-227, 1917.

MONTEVERDE, J. J. - Médio de cultivo semi-sólito com lactosa, uréa y doble indicador para selecionar Salmonelas y Shigelas. Sem. Med. B. Aires, 55: 846-847, 1948.

PUPO, A. - Bacteriologia da água. Isolamento das bactérias patogênicas. Anais Fac. Med. Paraná, 2 (1): 41 - 51, 1959.

RUSSEL, E. J. - The isolation of typhoid bacilli from feces with the description of a new double sugar tube medium. J. Med. Res., 25: 217-225, 1911.

SINGER, J. - Culture of Enterobacteriaceae - I - A pratical medium containing tryptone, lactose and indicators. II -- Use of urea triple stigar agar. An. J. Clin. Path.. 20: 880-885, 1950.

SURRACO. N. L., y V. R. PEREYRA - Nuevo medio de cultivo paar el repicado de colonias en el aislamento de Salmonelas y Shigelas. Arcb. Jrug. Med, Cir. Espec., 21: 518-523, 1942. 


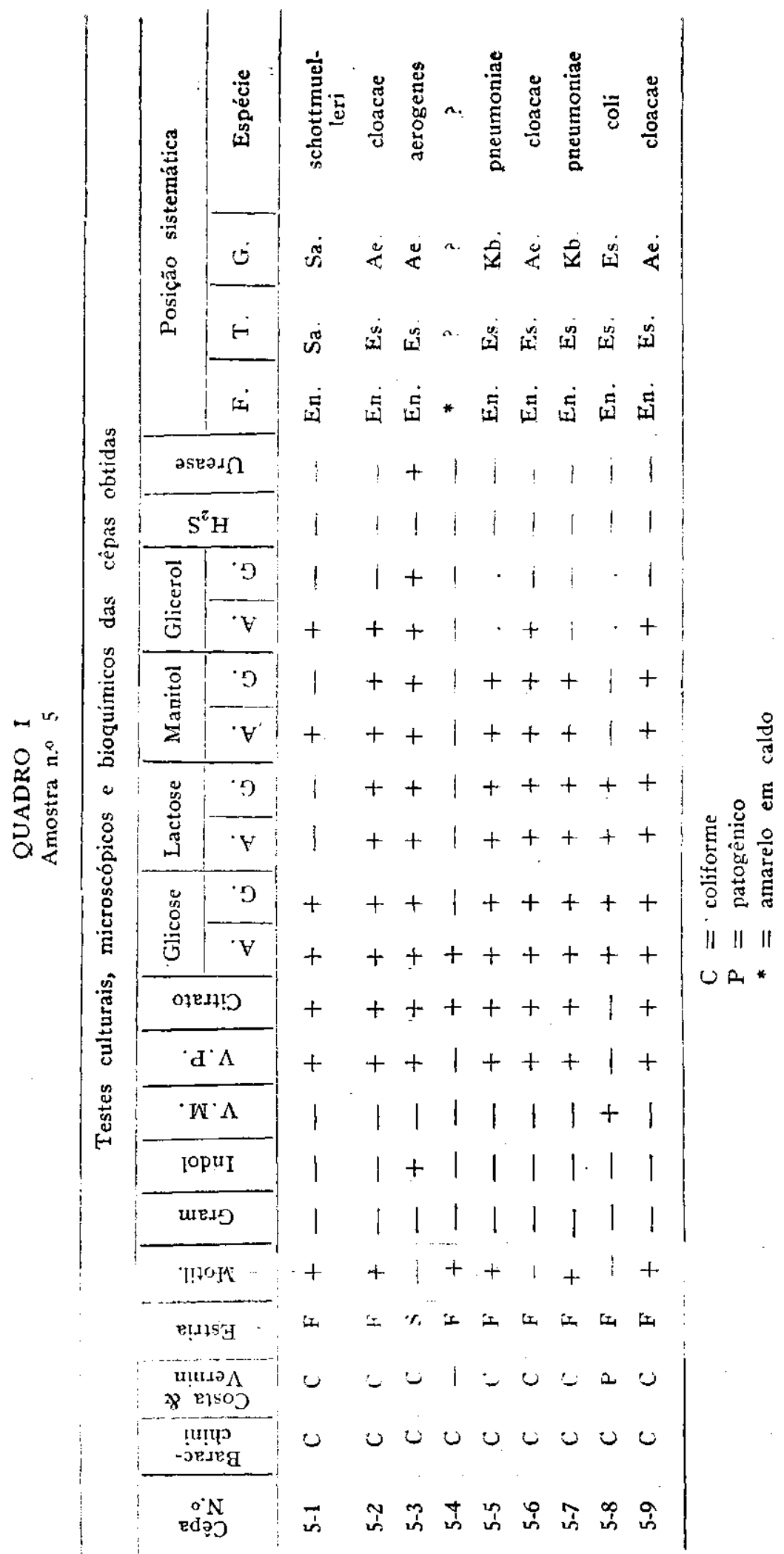




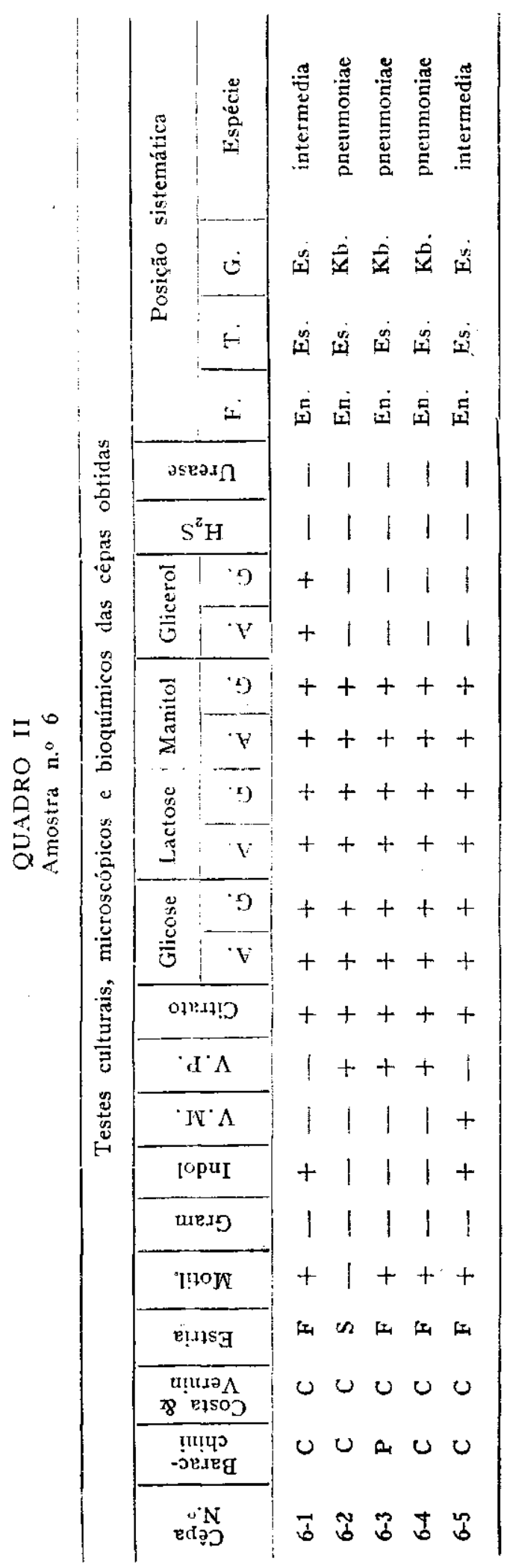




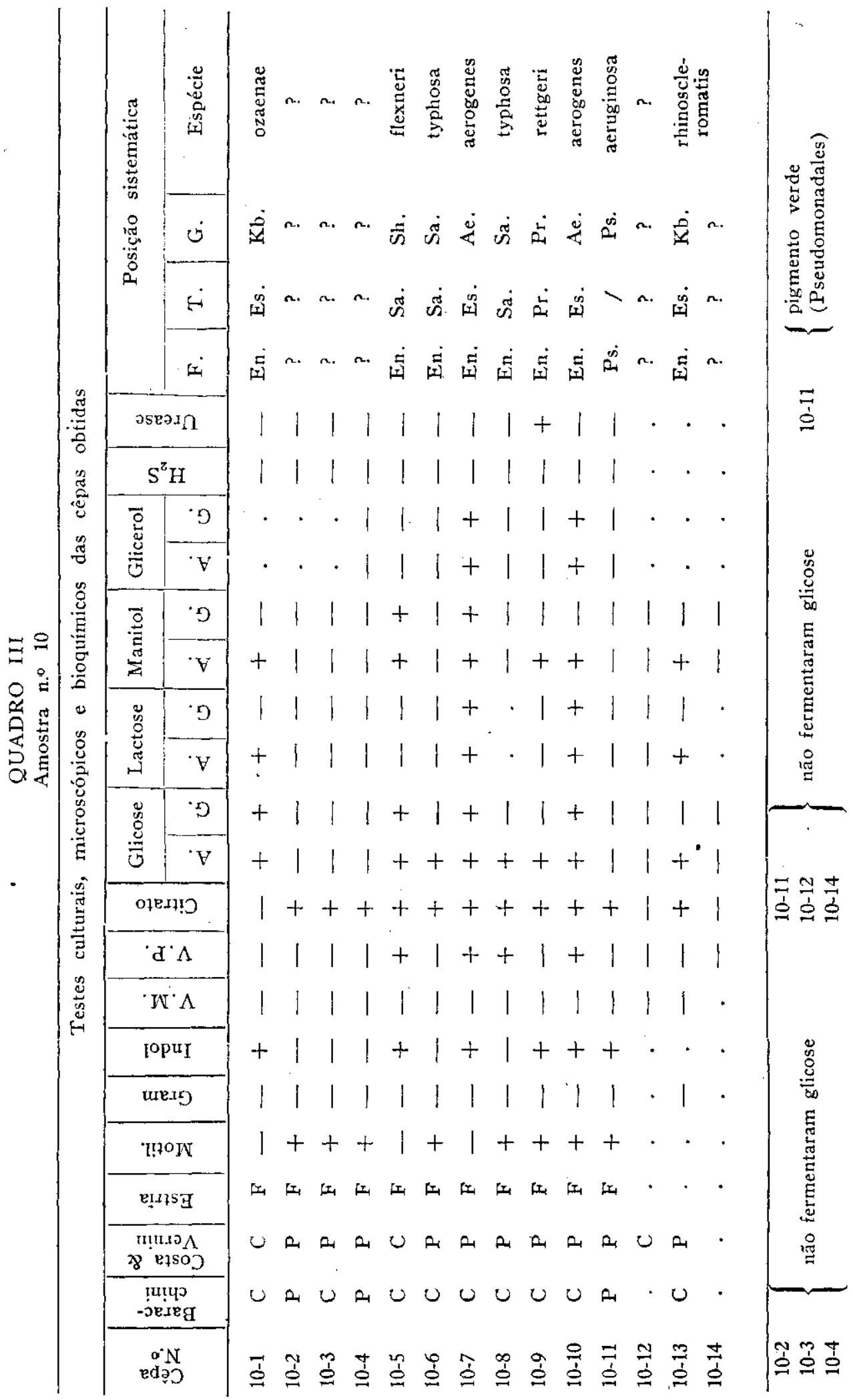




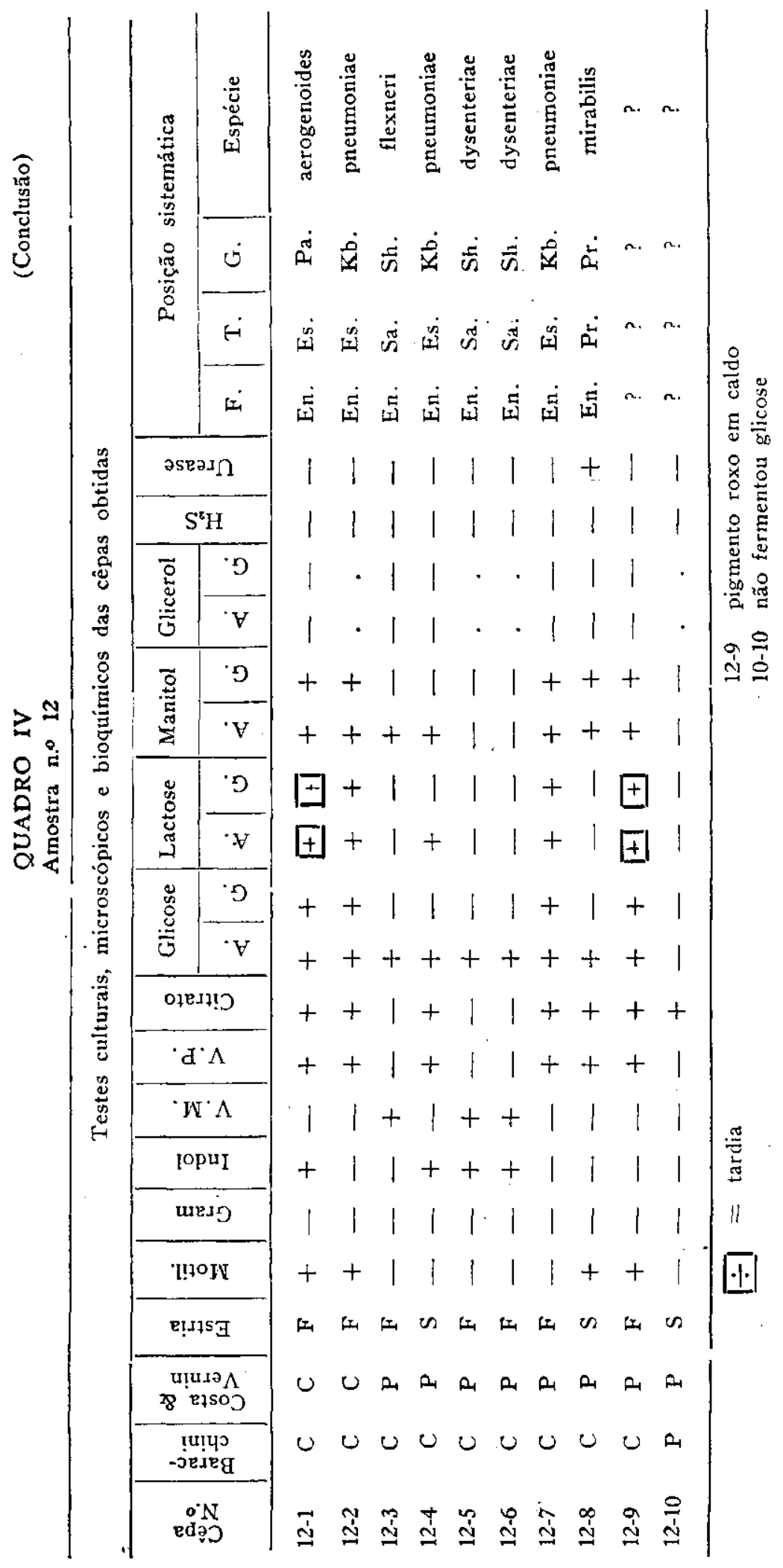




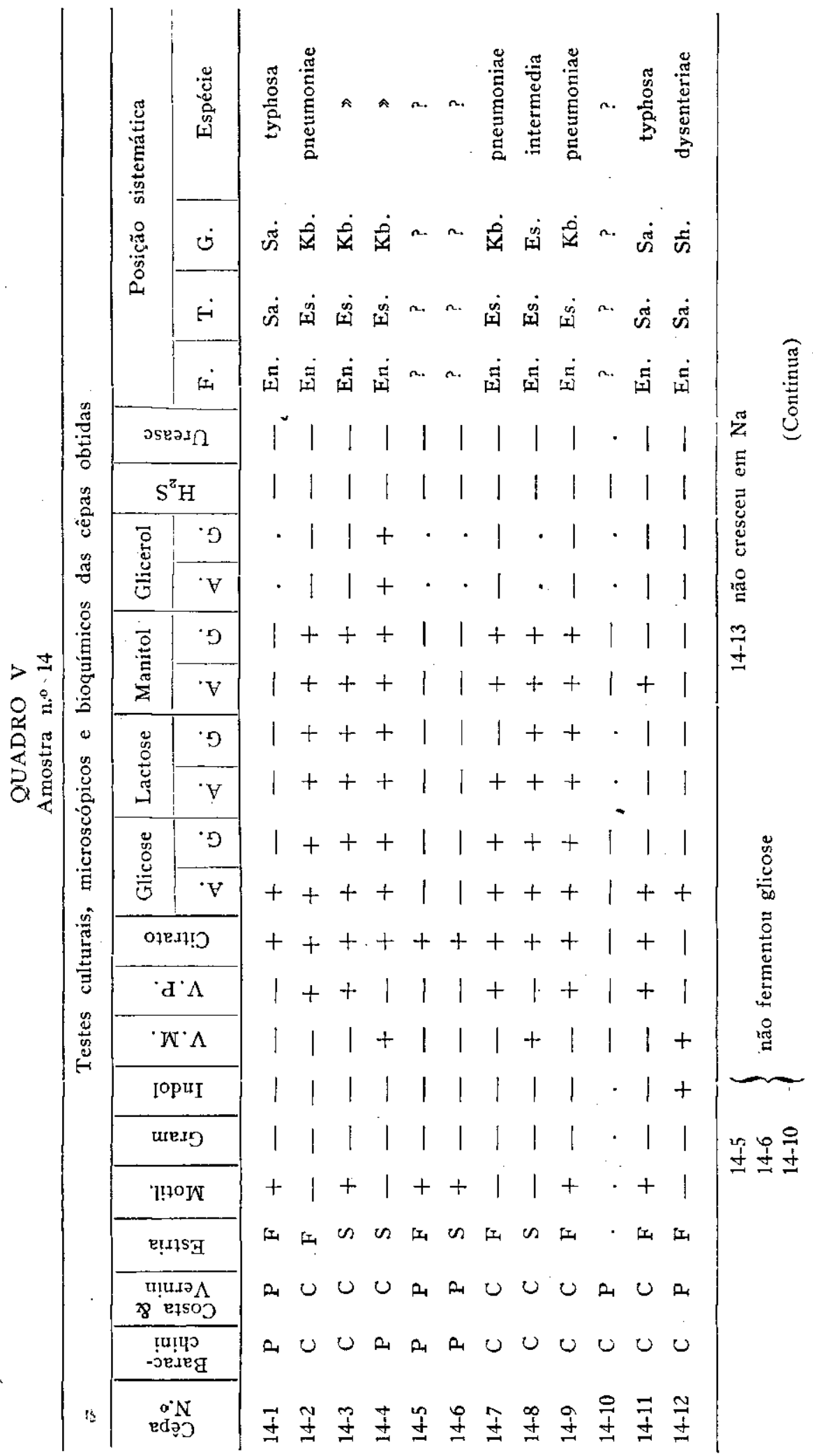




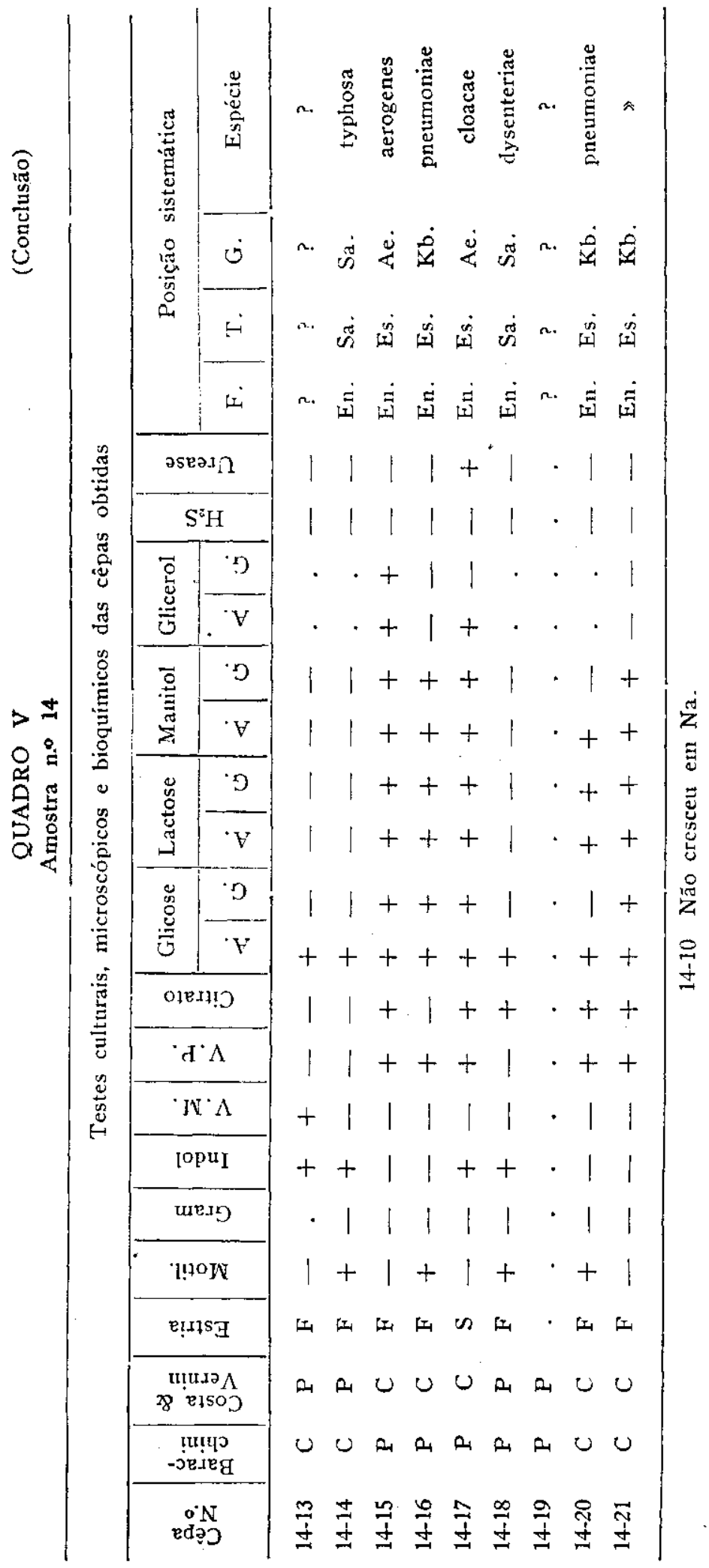




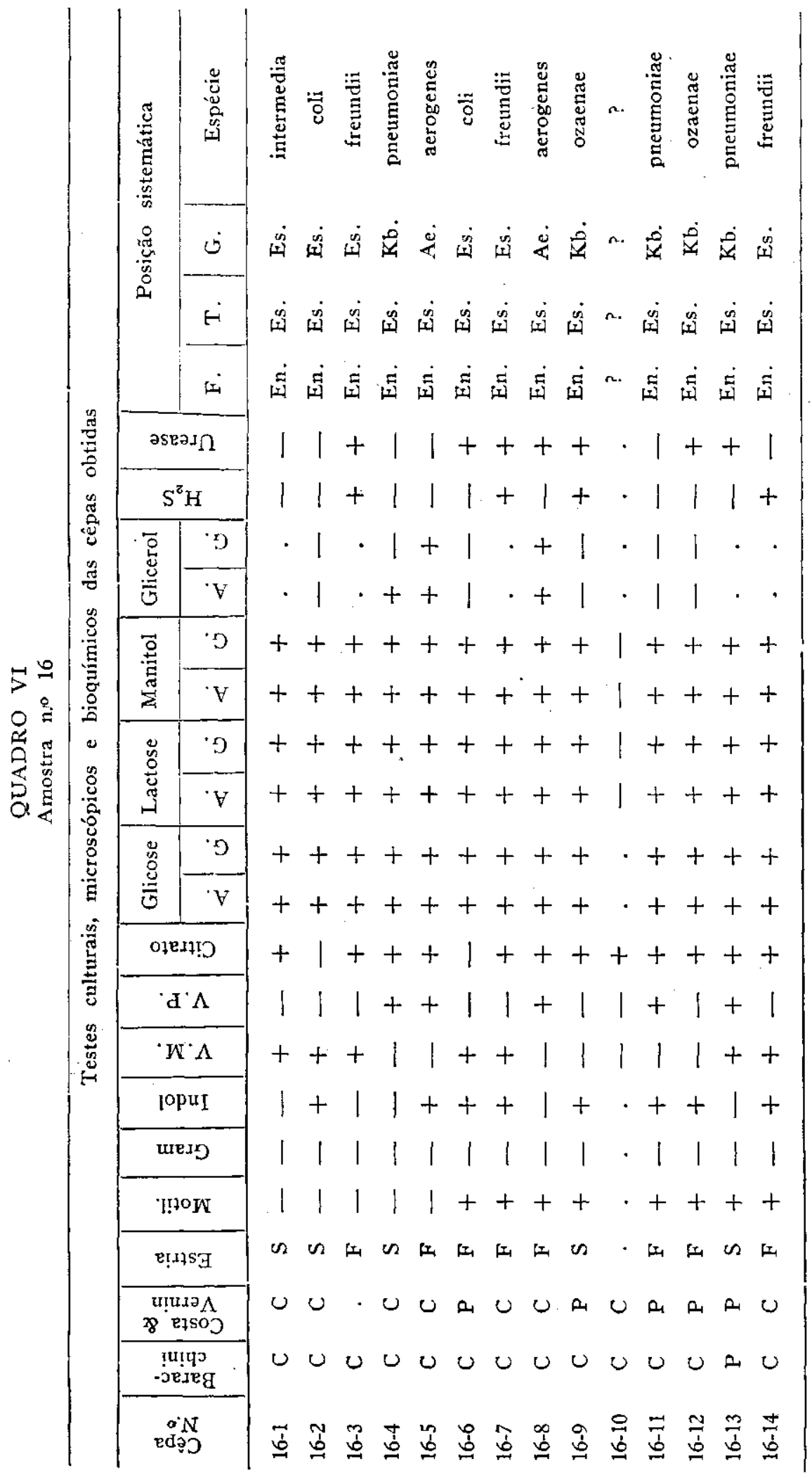




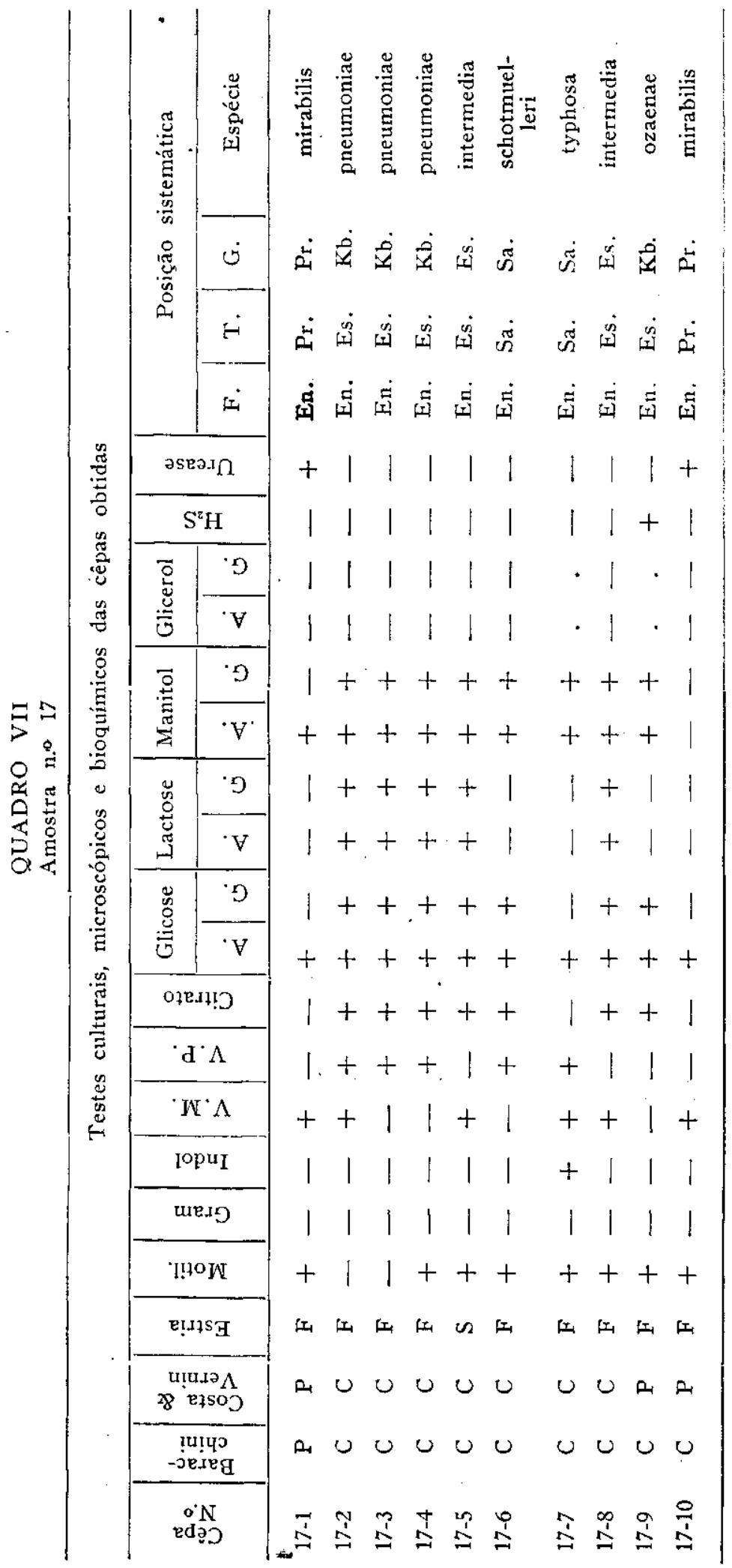




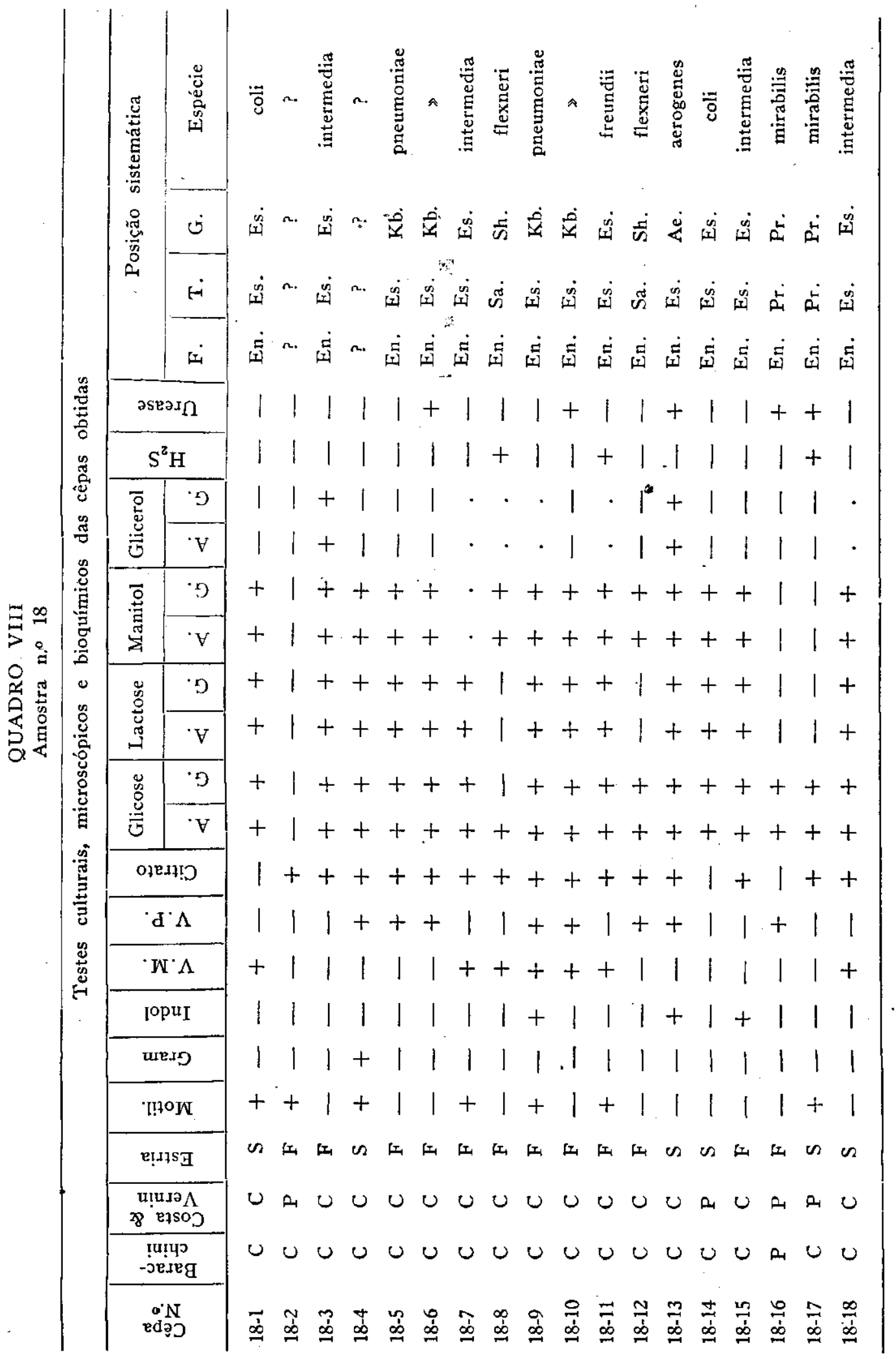




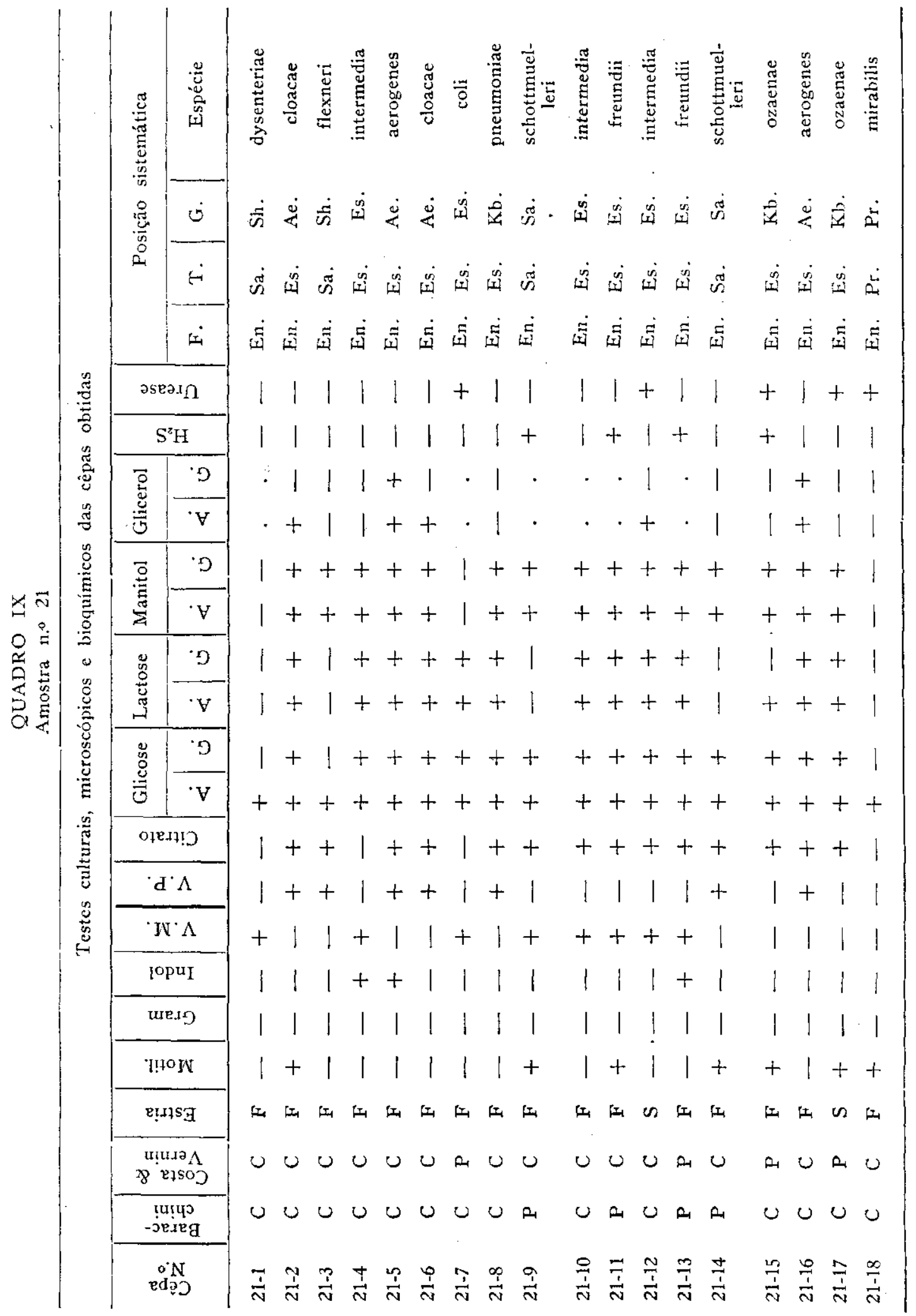




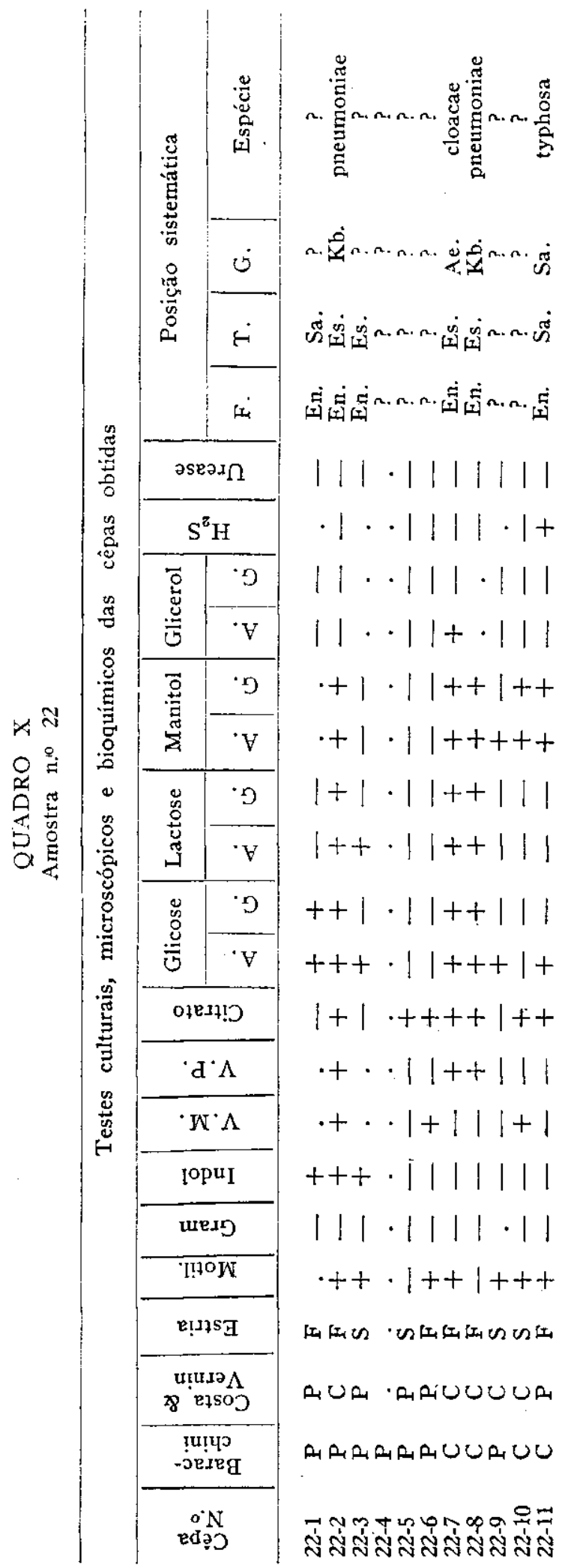




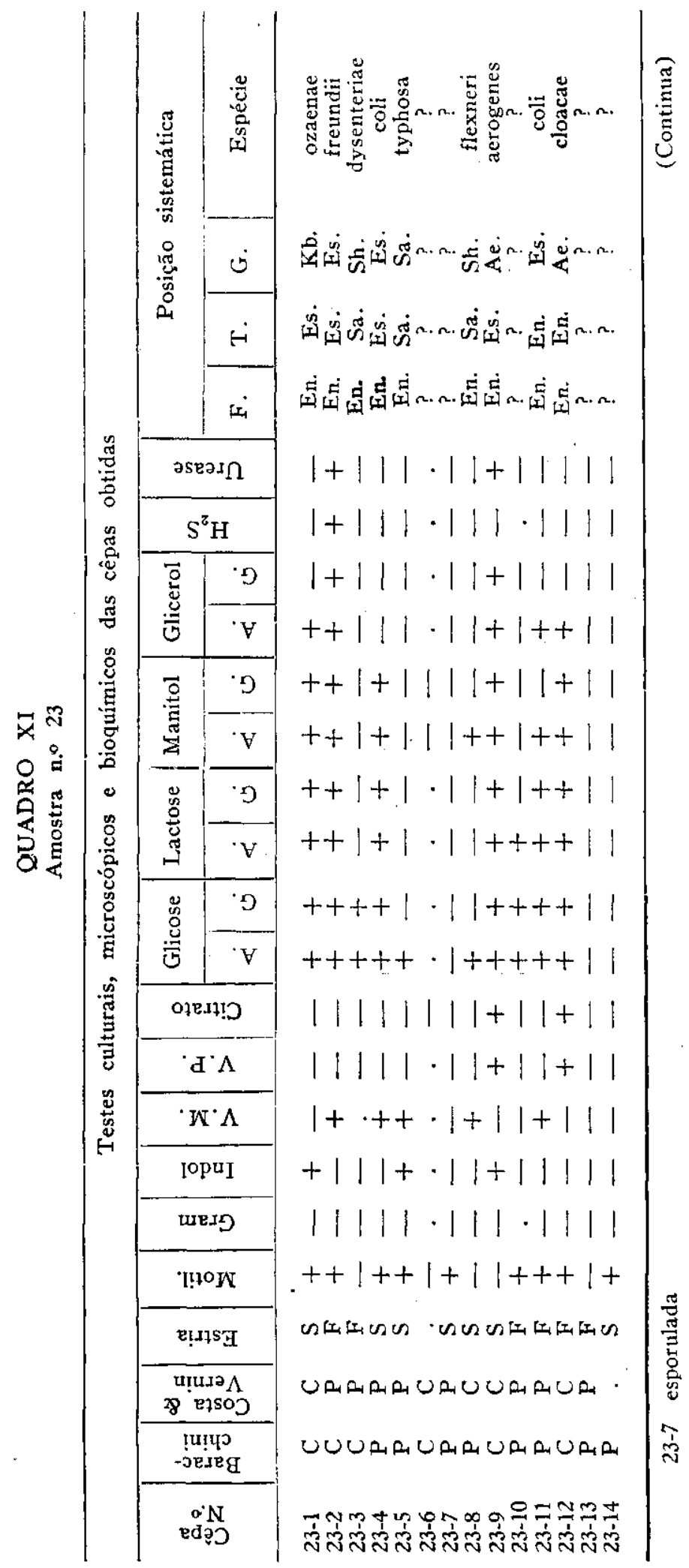




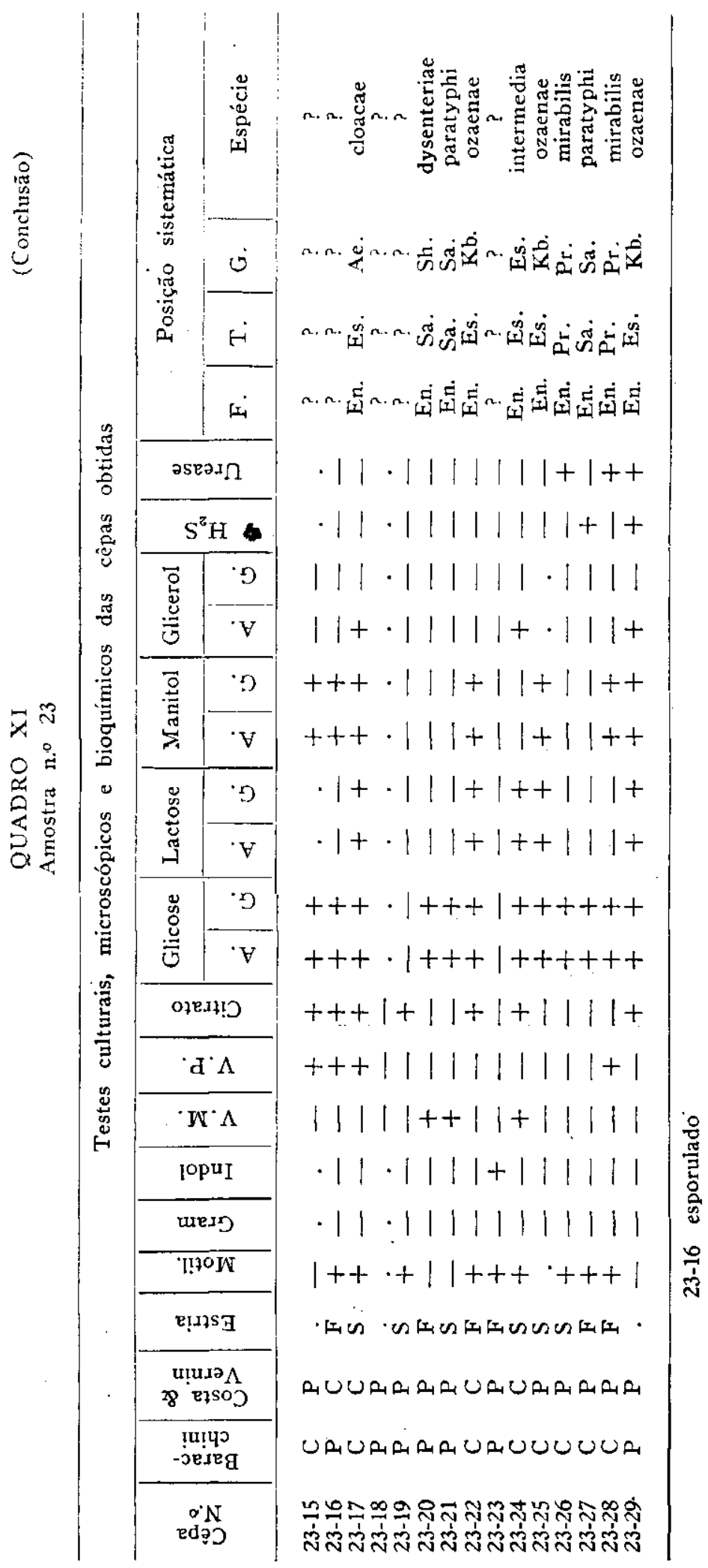




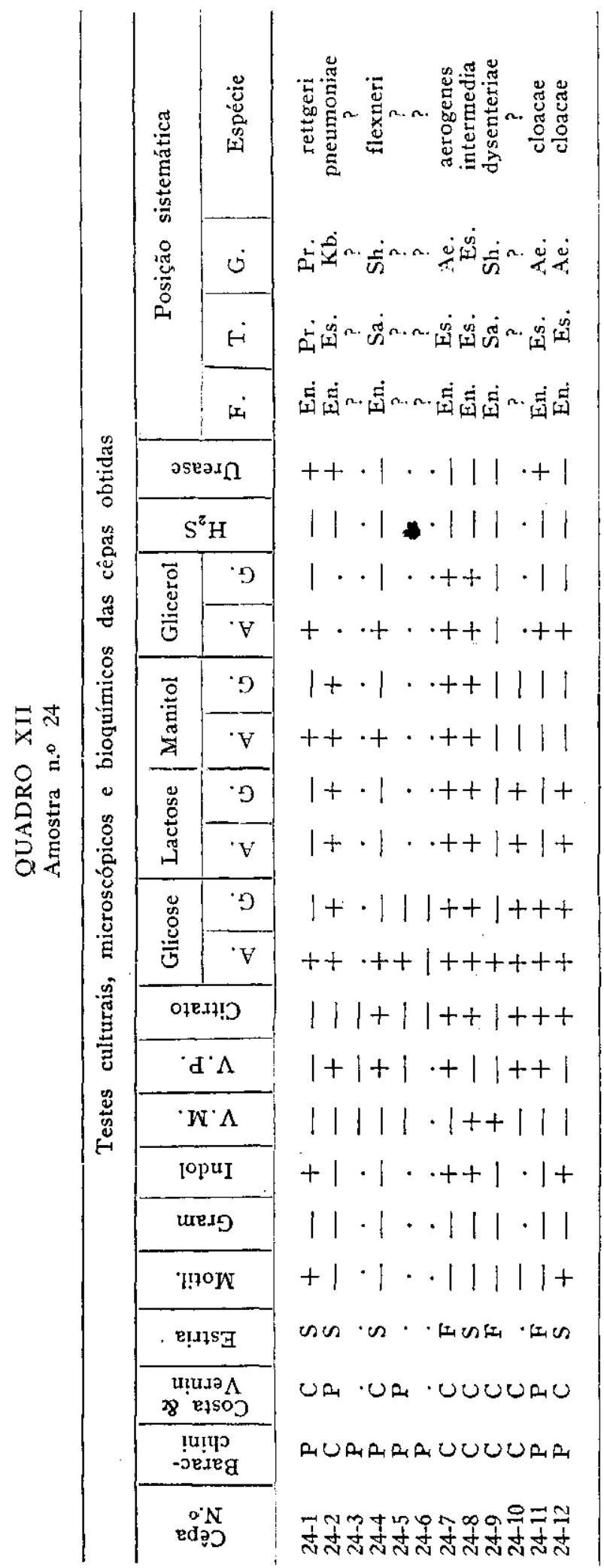




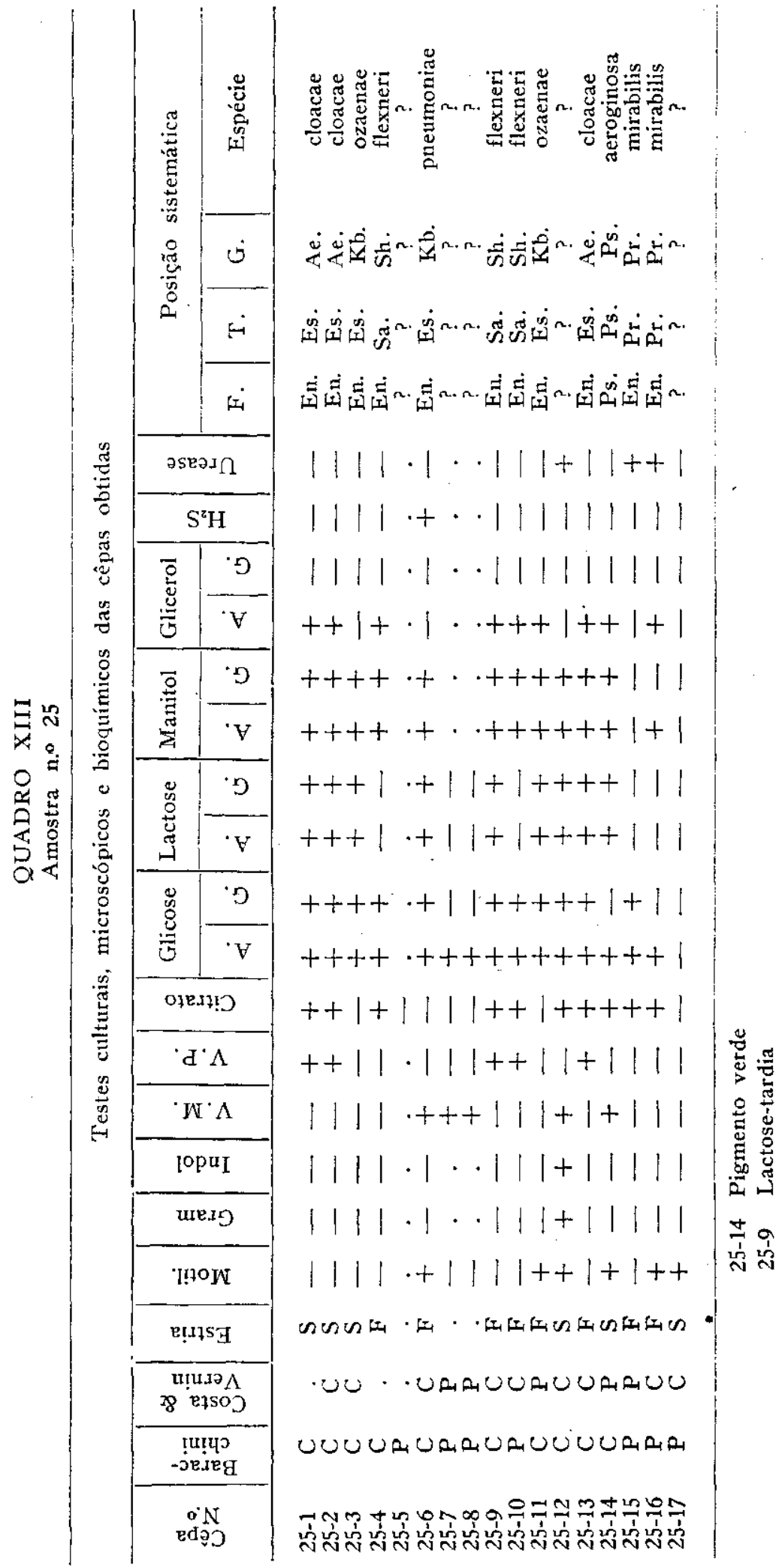




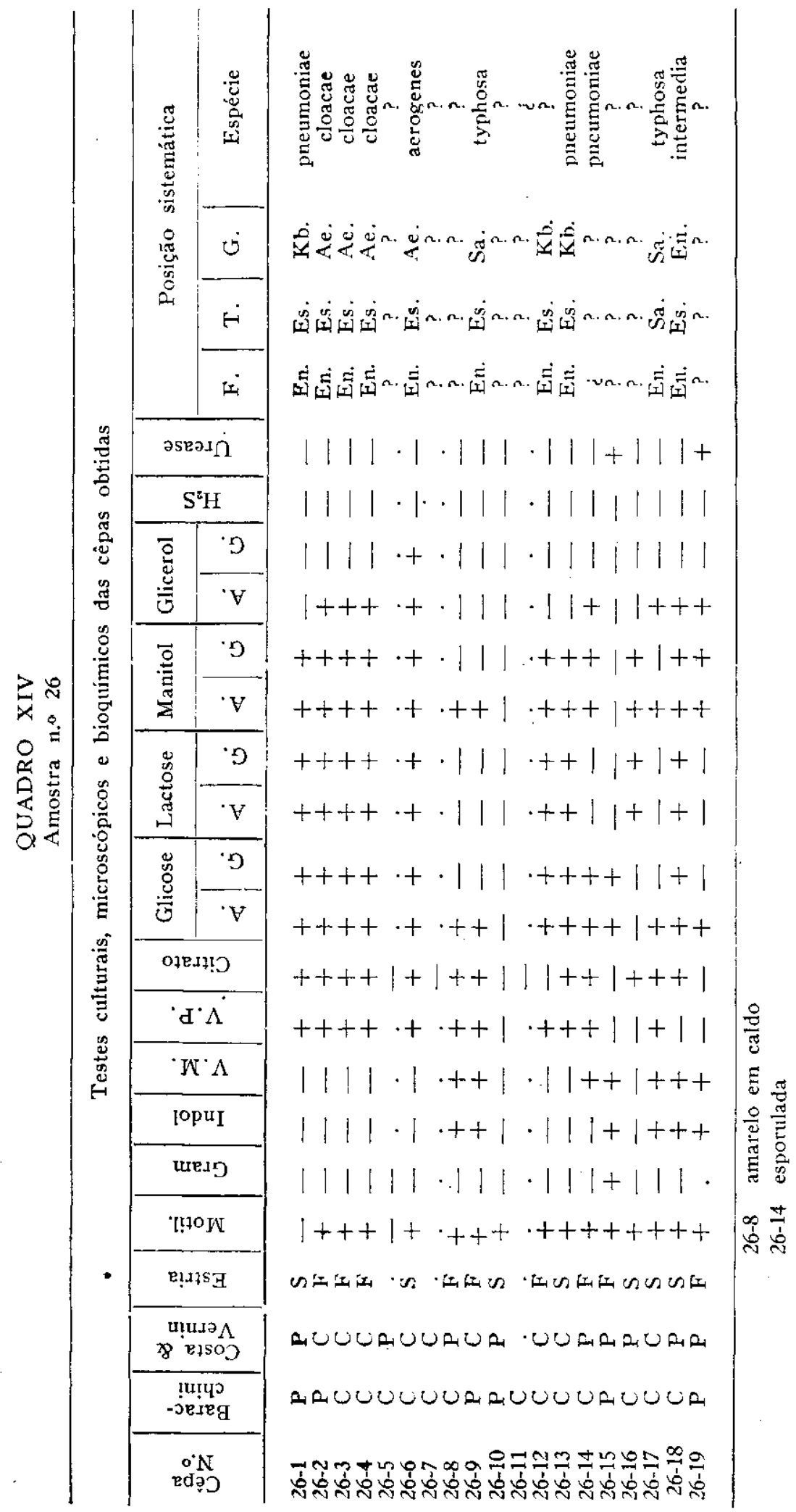




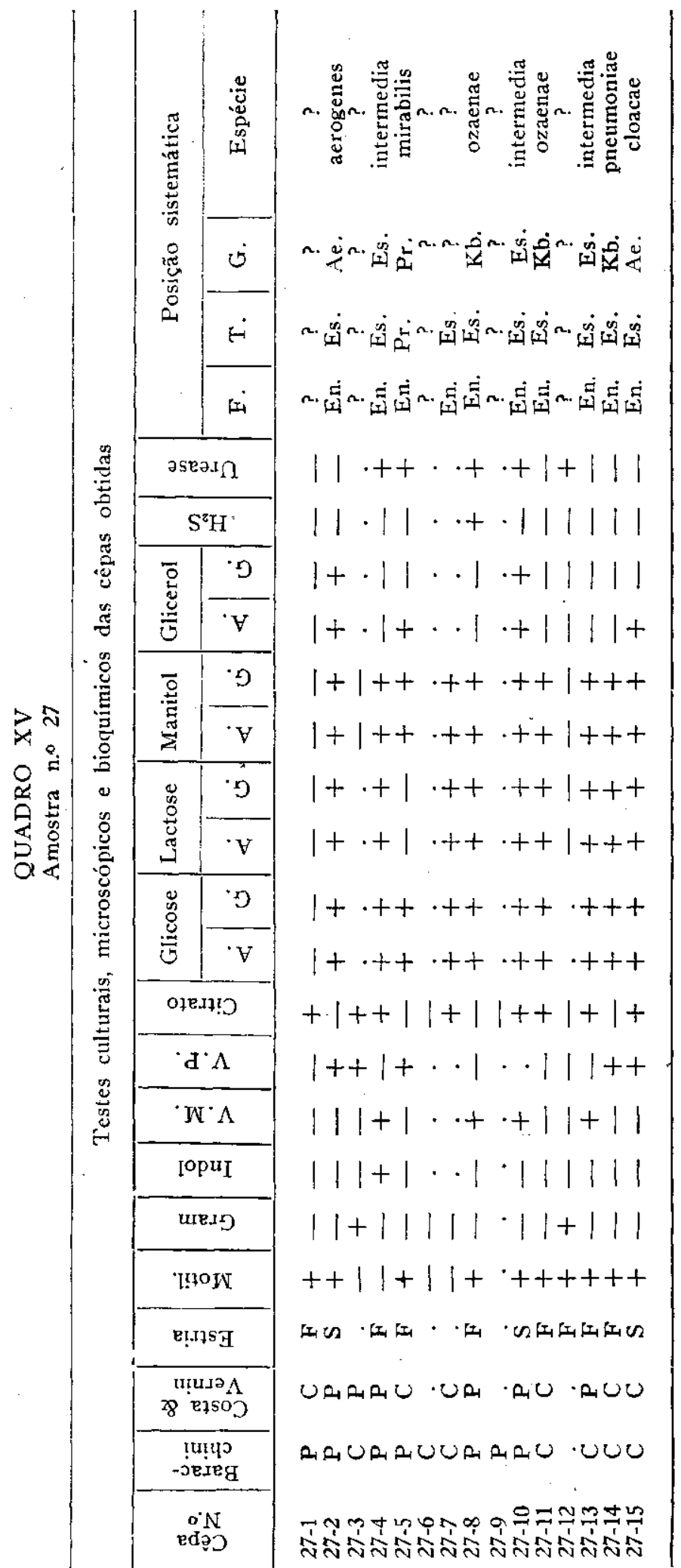




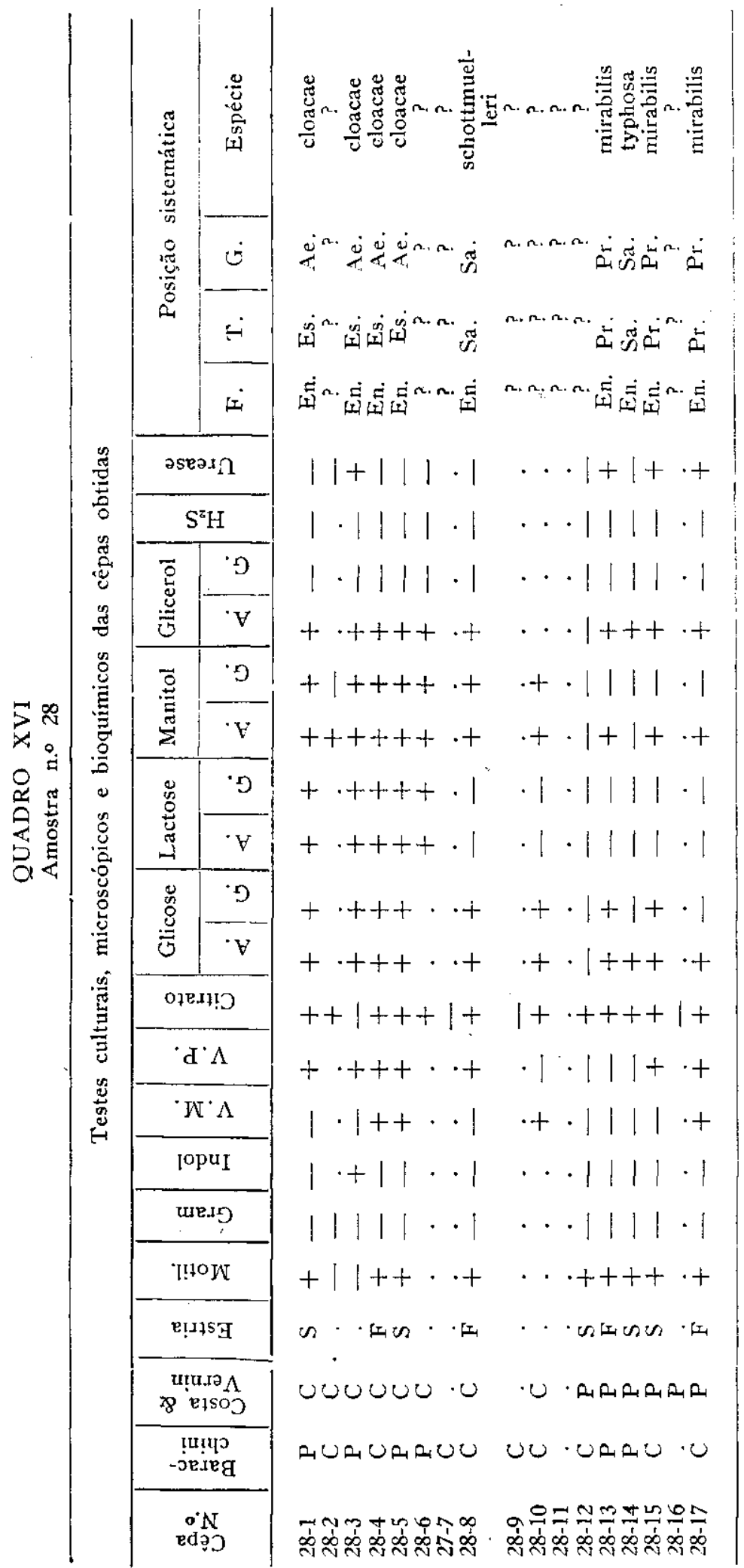




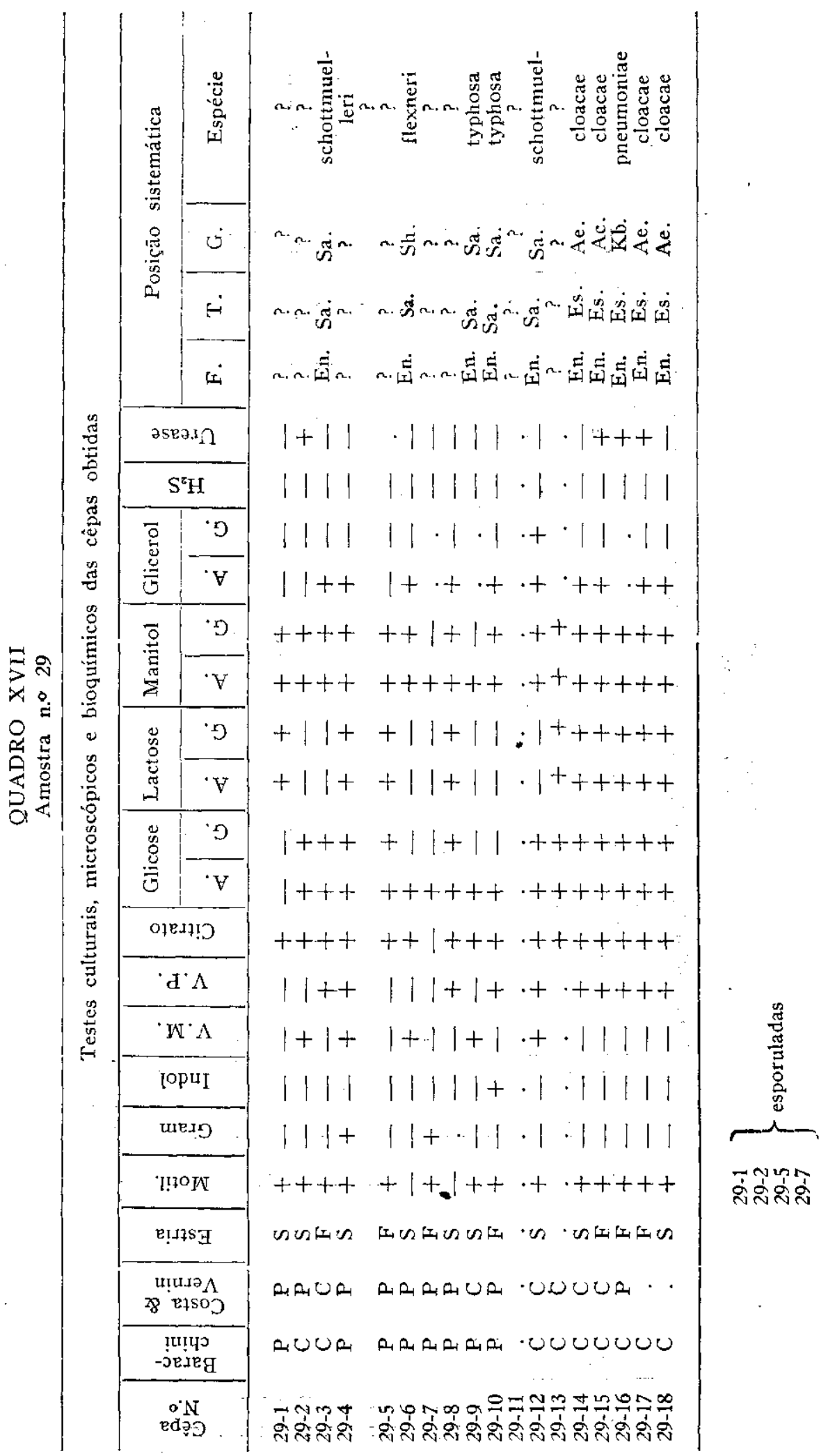




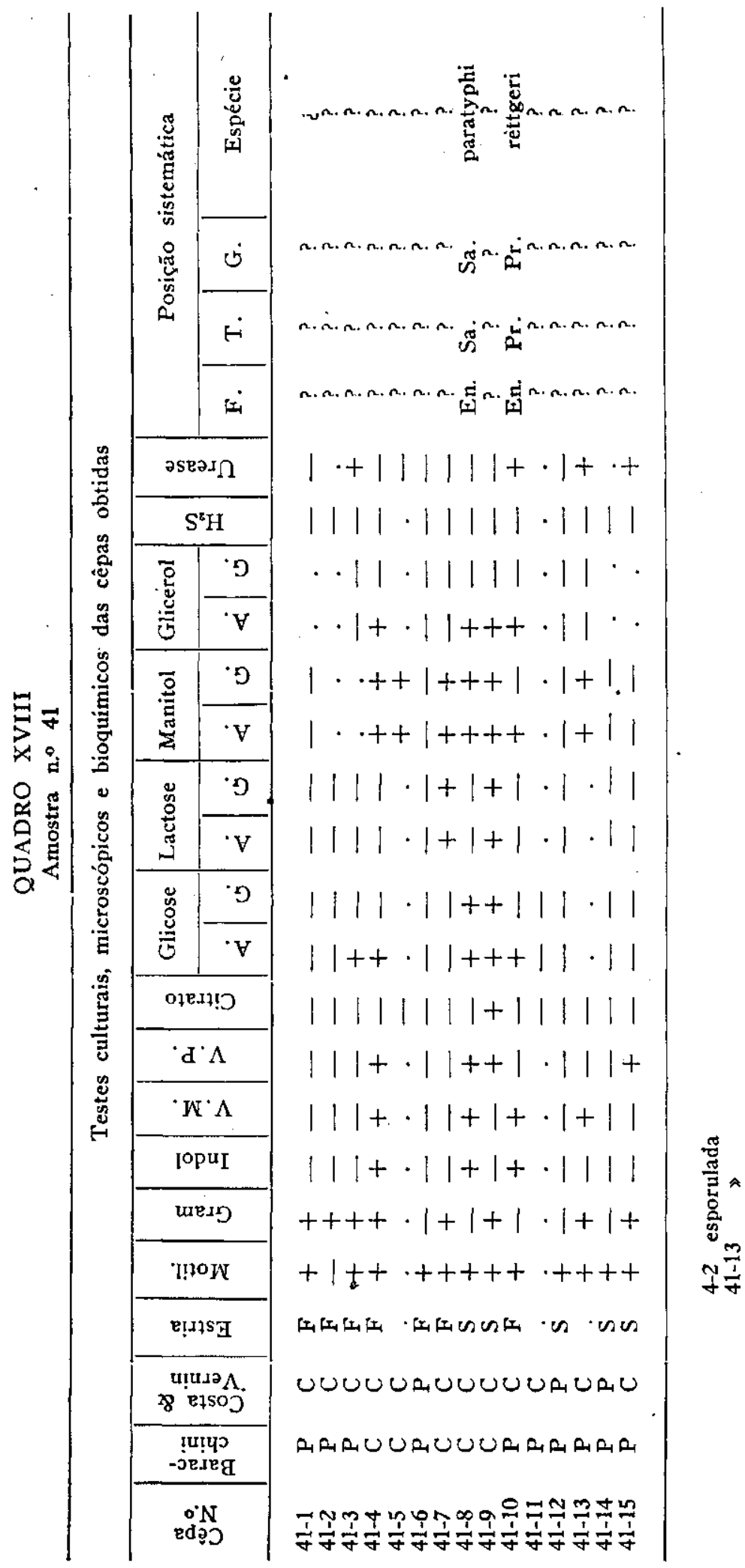




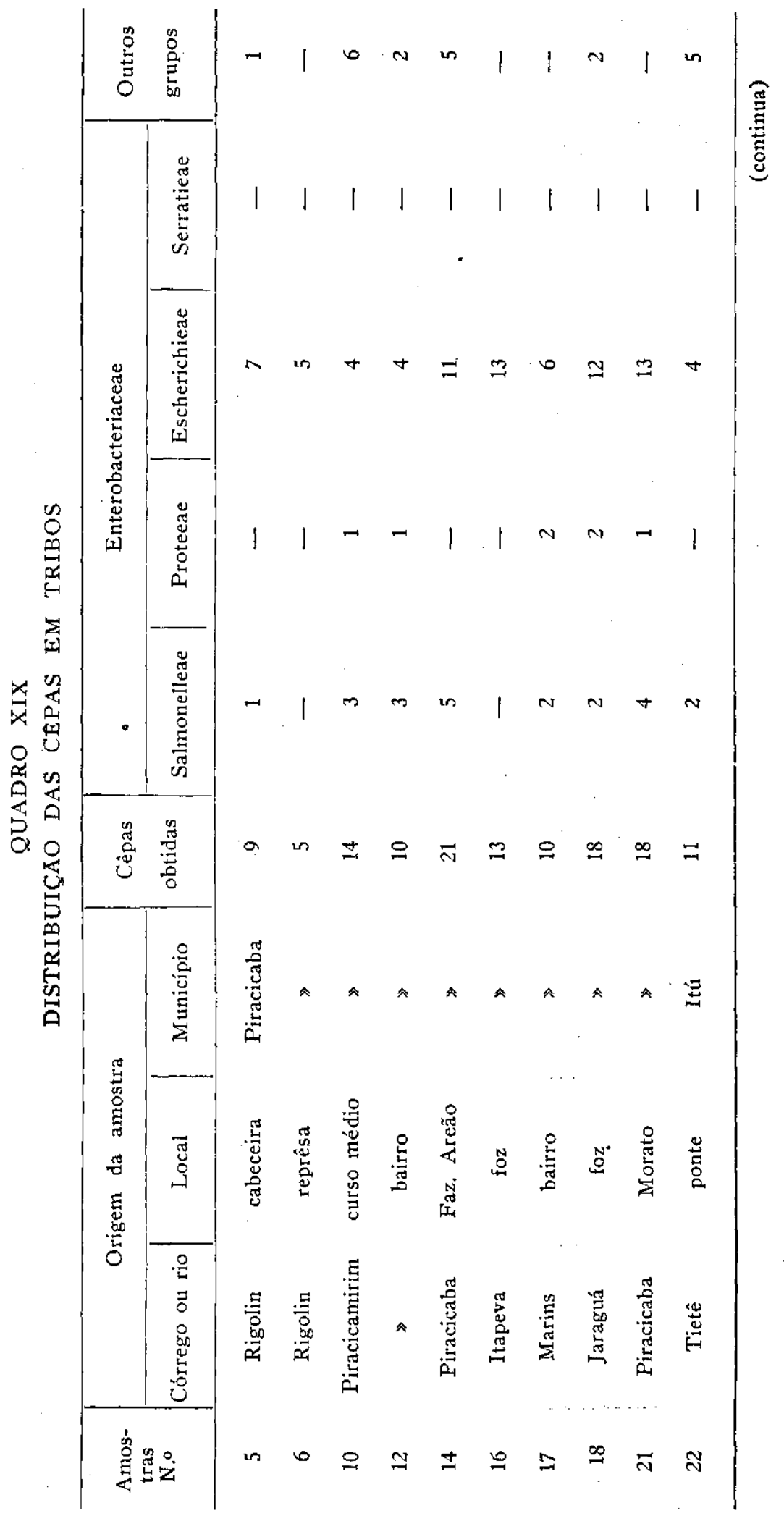




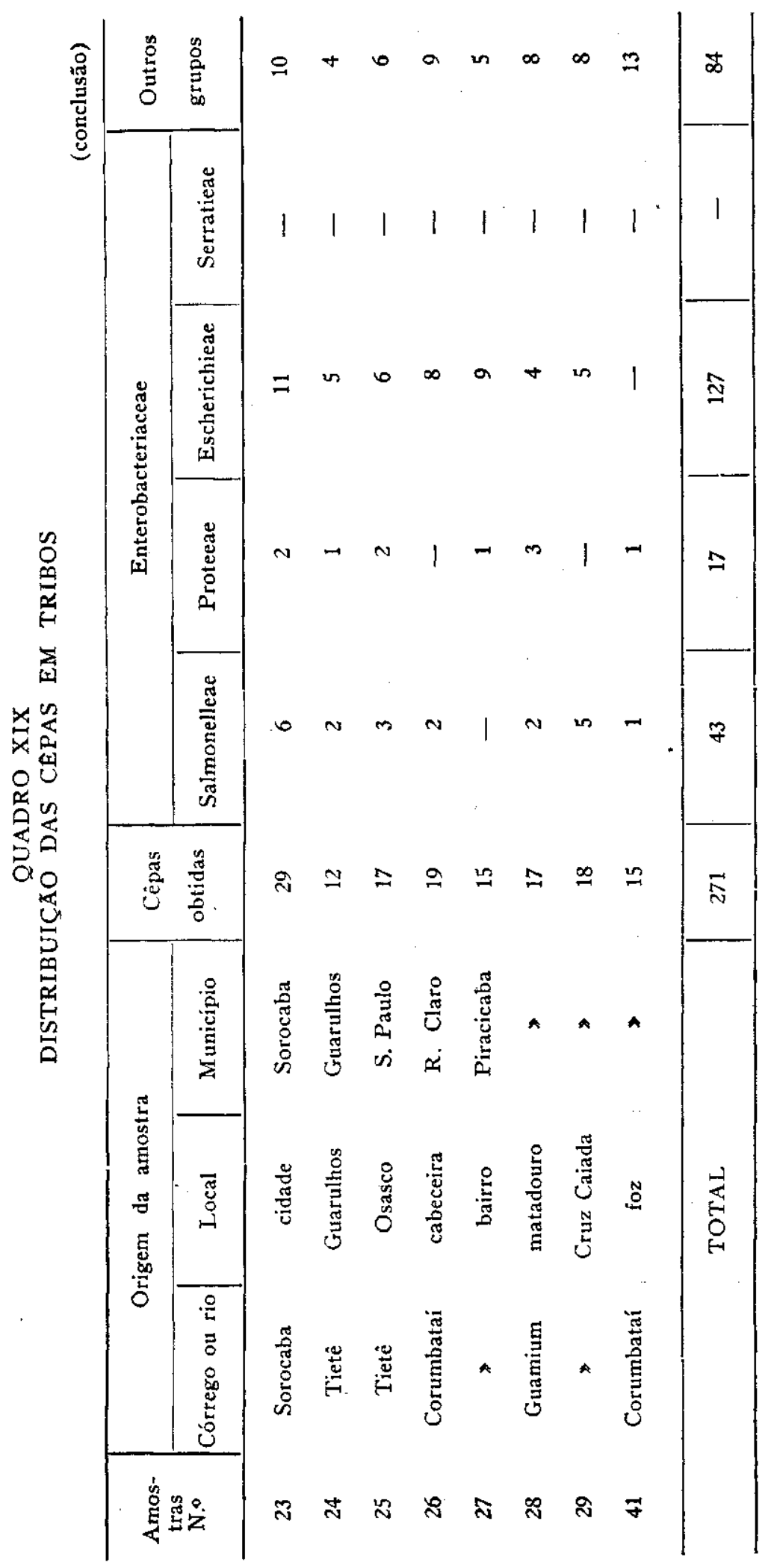




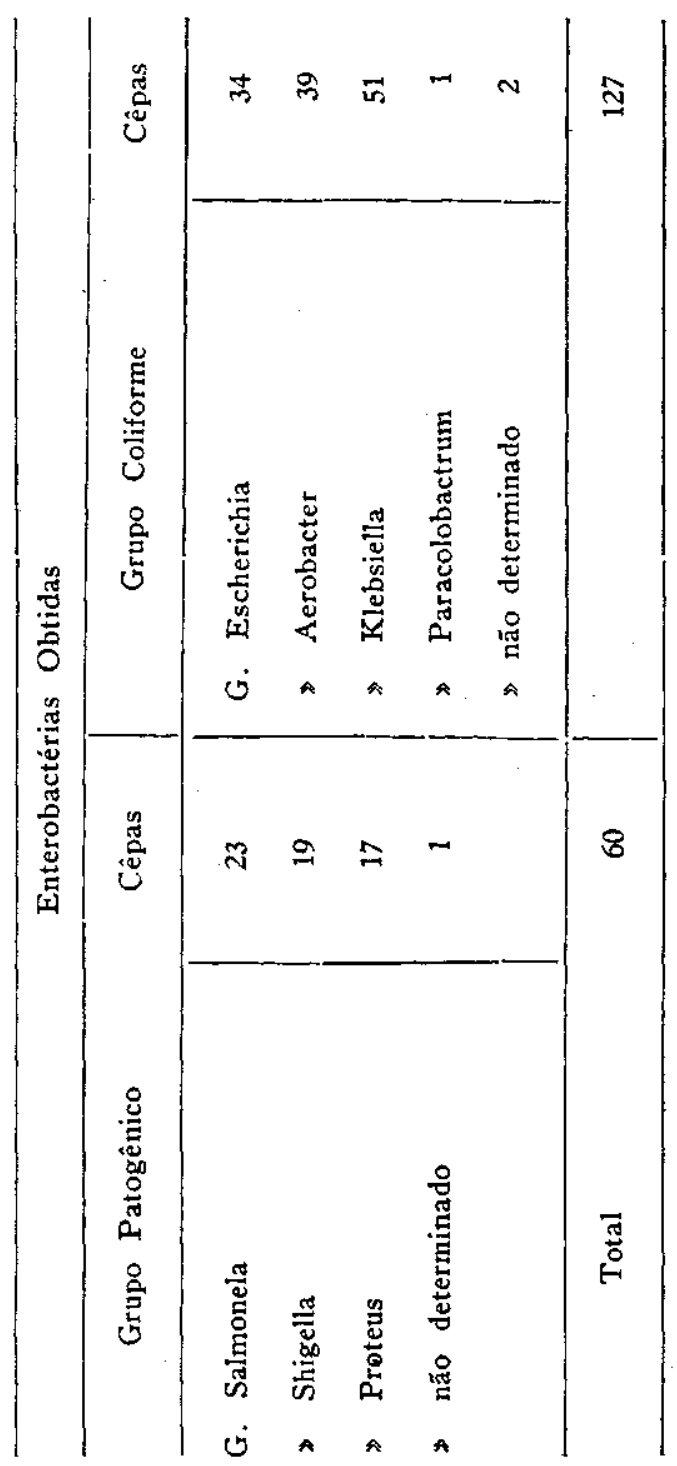




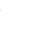

